\title{
Balancing of Rights in Land Law: A Key Challenge in Kenya
}

\author{
Peter Onyango O \\ School of Law, University of Nairobi, Kenya \\ *Corresponding Author: peter.onyango@uonbi.ac.ke
}

Copyright (C) 2014 Horizon Research Publishing All rights reserved.

\begin{abstract}
The attempt to revive African customary law has been persistent throughout the history of legal education in Kenya. Today more than ever before the country shall have to reconsider the role and importance of re-studying customary land tenure practised by the Kenyan people in order to strike proper balance of rights in land law in force. The research examines the balance of several interest groups and regulatory systems that confer rights to individuals and groups. The main concern of the research is about the deployed systems that have failed to quell conflicts, violence, crimes and injustices, related to land tenure and its inequitable redistribution to individuals and communities. The work seeks to provide clue to legal lacunae existing in the Kenyan land regime. As most of the problems facing land law are premised on the mechanisms, structures and policies adopted by the Government to put records straight, restore law, and order, the study investigates the effectiveness of such balancing criteria.
\end{abstract}

Keywords Rights In Land, Reform, Commission, Customary Law, Land Use, Policies, Economy, Law, Propriety, Land Tenure, Principles of Land Law, Human Rights

\section{Historical Background}

Land issue is not new in Kenya and it has been at the centre of controversy before, during and after British historical occupation. ${ }^{1}$ Actually, it has been the fulcrum of cartels and high level of chronic corruption ${ }^{2}$ that has tainted the country's image for quite a lengthy period of time. ${ }^{3}$ The centrality of land in the economic environment is an issue that has not been resolved by policies and legislations in place since the independence in $1963 .{ }^{4}$ The period following

1 Frederic Jenny, 'Cartels and Collusion in Developing Countries: Lessons from Empirical Evidence' (2006) 29 World Competition 109.

2 Kim Matthews and William H Coogan, 'Kenya and the Rule of Law: The Perspective of Two Volunteers' (2008) 60 Maine Law Review 561.

3 Roger Southall, 'The Ndungu Report: Land \& Graft in Kenya' (2005) 32 Review of African Political Economy 142.

4 Simon F.R. Coldham, 'Land-Tenure Reform in Kenya: The Limits of Law' (1979) 17 The Journal of Modern African Studies 615. the end of the British colonialism has been referred to as the indigenous misrule ${ }^{5}$ under the failure of the constitutionalism and the rule of law. ${ }^{6}$ However Kenya mastered the game from the colonial master - misuse of the judiciary and police to render the population economic, social and emotional paupers. ${ }^{7}$

The work seeks to discuss some of the unaddressed key historical and current challenges facing balancing of rights in land law through legislation, policies, and institutional commissions. 8 The evaluation shall include the capacity of the current Governments to enhance comprehensive, transparent and inclusive land reforms which will redress all historical injustices over customary land tenure, equitable redistribution, and, most importantly why Kenya is not making headways so far.

Land is of fundamental concern in economic and political development. In African contexts discussion of land is commonly framed by questions of how customary land tenure systems are moving towards private property models involving land markets. Empirical studies remain sparse, but the evidence suggests that, while land markets are becoming more common, disputes over the meaning of transactions are also increasing.

Land market has taken supremacy over social requirements in Kenya while the attention of policy and law makers dwindles around eminent serious agrarian injustice. The issue at hand is that Kenya finds herself in controversial situation when it comes to balancing rights in land law other than general economic, legal and political considerations. The best example is realised in the land reform and land tenure reform process that have been unsuccessful since the independence.

Change in the perception of land is inevitable. First and foremost it is necessary to divide the topic of land reform into land tenure reform (the establishment of secure and formalized property rights in land) and land redistribution

\footnotetext{
5 Matthews and Coogan, 'Kenya and the Rule of Law' (n 2).

6 Ibid.

7 Ibid.

8 Southall (n 3).

9 Jean-Philipe Colin and Philip Woodhouse, "Land Markets in Africa", in Africa, Vol. 80, Issue 1, Edinburg University Press,
} 
(the transfer of land from large to small farmers which respects all interested parties). ${ }^{10}$

The question involving balancing of interests in land law in Kenya must consider inter alia the inherited English common law system, British administrative system, English property Act and English law of Contract which still govern the jurisprudence on land. ${ }^{11}$ When the British left Kenya they transferred forms of democracy-Parliament, courts and administrative apparatus-to African Kenyans. They also transferred a demoralised judiciary, a violent, oppressive, and corrupt police force, and a contemptuous and venal bureaucracy. ${ }^{12}$

The same belief in land as a property for economic benefits made British jurists come up with "waste-land" theory which holds that if a piece of land lies idle (without being beneficially utilized), then such land can be legally apportioned to someone or some entity or authority that would turn it into proper economic use. This is a principle linked to utilitarian notion of land as a utility which should not lie idle. The same argument dominated the debates on the crime of colonization and continues to haunt land transfer polices and agrarian change in Kenya. 13 For instance, is it right that citizens die of hunger while a large chunk of arable land is allocated for national animal reserves? Couldn't such public lands make more logical sense if they were converted into agricultural use to provide sufficient food?

As the quick solution to such questions remain increasingly remote the logical argument turns to the question of balancing of interests in land law as the most crucial issue determining political economy of Kenya. Since independence Kenyan Governments have taken note of the need to reform land policies and law, and also to address most of the crimes related to land especially graft, misuse, and unfairness in its distribution. What has not been properly addressed is how to create a balance in several policies and laws that give rights over land such as customary land tenure, distribution strategy, statutory law and market based theory.

Consequently any right thinking person would ask how and why did Kenya get to where it is today with her land issues? Such question can better be explained by looking at how rights in land have been manipulated by various regimes and stakeholders before, during and after the British colonization. The genesis of balancing of rights in land and serious socio-economic and historical injustice that has never been properly addressed shall lead us to understanding some of the critical legal bottlenecks that still haunt the modern State frustrating her development visions.

\section{a) The Genesis of Rights in Land}

We are made to believe that "White Settlers" from South

10 ROGIER VAN DEN BRINK, HANS BINWANGER, JOHN W. BRUCE, Consensus, Confusion, and Controversy: Selected Land Reform Issues in Sub-Saharan Africa, World Bank Working Paper.

11 Catherine Boone, 'Land Conflict and Distributive Politics in Kenya' (2012) 55 African Studies Review 75

12 Matthews and Coogan, 'Kenya and the Rule of Law' (n 2).

13 HW Wilkinson, 'Law Commission: Transfer of Land. Report on Restrictive Covenants' (1967) 30 The Modern Law Review 681.
Africa and also from England who acquired fertile pieces of lands in the arable Kenyan Highlands for their needs of large-scale farming operated independently from the colonial Government. Some parts of Laikipia, Rift Valley, and Mau Escapements were apportioned to the "White Settlers" by the colonial Government for industrial farming activities on the theory of "waste land". Some of the indigenous communities (the natives) that were living on such lands were consequently turned into squatters through some technical resettlement schemes. Lots of persons that lost their lands were forced to live in designated locations with home-guards that would ensure that in furtherance would not create any undesirable disturbances. Instead communities with nomadic system of socio-economic life were divided into provinces with patched lands good for free grazing namely the Masai in the South Rift, Nakuru and also Nairobi. ${ }^{14}$

Around this time, the colonial administration started negotiations with the Maasai over the transfer of land. This culminated in an agreement, signed in 1904 and 1911 between the Maasai and the colonialists in which the Maasai handed over rights to land in Nakuru, Naivasha and Laikipia to white farmers. The land signed over by the Maasai effectively dispossessed the Ogiek of their ancestral land. This was followed by another agreement in 1932 between the Maasai and the colonial authorities, which saw the handing over of Mau Narok to the colonial settlers. In 1936, the colonial authorities scrapped the Ogiek administrative unit that was formed in 1916. To the Ogiek, the Maasai -colonialists agreements were done in bad faith and only a group or sections of the Maasai lost their lands but not the whole group as portrayed by the agreements. If indeed the agreement was genuine, it should have mentioned other communities who were stakeholders in the lands. 15

Historical injustices concerning rights in land in Kenya and the aftermath of all this is what we term as continuous search for balancing of rights mechanism that if well implemented will yield into the greatest satisfaction needed for the largest number of the population possible. Laissez-faire status and maintaining the status quo that has been termed as the perpetuation of corruption and impunity in Kenya may not do justice to the already ailing socio-economic and justice system due to injustice linked to land.

Since such native communities did not have sufficient advanced legal capacity to reject or accept the domination of aliens (foreign occupancy and appropriation of land), the natives could only resort to use of force as in the case of Mau-Mau revolt $(1952-60)^{16}$ in furtherance to claims for their rights of self-determination and independence using

14 'Ogiek Land Cases and Historical Injustices by Towett J. Kimaiyo' <http://freeafrica.tripod.com/ogiekland/book/Chapter05.htm $>$ accessed 17 August 2014.

15http://freeafrica.tripod.com/ogiekland/book/Chapter05.htm

16 Matthews and Coogan, 'Kenya and the Rule of Law' (n 2). 
military tactics. 17

The wars for independence were caused by the question of rights over land 18 which had been unjustly apportioned to the "White-Settlers" by the colonial regime. The British did not take sufficient regard of customary land tenure and particular rights to land proprietorship meant for the natives, a trend similar to that of South Africa. ${ }^{19}$

At the independence in 1963, Kenyan political leadership did not reverse the understanding of land tenure adopted from the English Property law and instead perpetuated the same colonial trend of land as property for commercial benefit. Real estate or trade in real estate in Kenya has been booming among the business and political communities since the independence. Ruling elite ${ }^{20}$ rush to acquire private lands and get the title that enables individuals to acquire and dispose land under the Property Act. At the same time land grabbing of public lands became another question of injustice in Kenya and an issue of public interest in the recent years. ${ }^{21}$

Governments have not come up with policies and regulatory mechanism that will streamline the balancing of rights in land law making the question of land rights more deplorable with time. Local elites inherited the British institutions along with national poverty. The elite opted for the retention of power whatever what it means to get out of poverty. The first President, Jomo Kenyatta, inherited authoritarianism from the British colonial power, and used various forms of bribery and intimidation to convert public lands into his own use and that of his political allies. ${ }^{22}$ President Daniel T. Arap Moi, in his 24 years, inherited the same corruption and impunity from his predecessor at the detriment of the rule of law. Corruption became a way of life in Kenya. ${ }^{23}$ The hope of the multitude of Kenyans was raised when President Mwai Kibaki took over from Moi in 2002 with the promise to restore constitutionalism and the rule of law, a promise that was betrayed. In 2005, a national referendum was held to decide on the new constitution for Kenya and Kibaki and his allies lost dramatically against the Orange Democratic Movement. However, still his government was reluctant to bring the reforms Kenya needed, a situation that triggered off the explosive 2007 elections. ${ }^{24}$

\section{b) Current State of Affairs on Land}

The Republic of Kenya embraced structural adjustment strategy proposed by the international institutions including the World Bank, International Monetary Fund, and United Nations to privatize most of its institutions in order to prop up development process in 1993. One of the crucial things that the Government was to handle immediately was the land

17 John Newsinger, 'Revolt and Repression in Kenya: The "Mau Mau" Rebellion, 1952-1960' (1981) 45 Science \& Society 159.

18 Ibid.

19 Matthews and Coogan, 'Kenya and the Rule of Law' (n 2).

20 Southall (n 3).

21 Matthews and Coogan, 'Kenya and the Rule of Law' (n 2).

22 Ibid.

23 Ibid.

24 Ibid. law. Legislations on land were enacted to bring law and order in the questions of land but policy makers and legislators stuck to the English legal principles on land as a property.

Beneficial economical conception of "land" in Kenya is still holding principles drawn from the English Common Law and traditions. The Kenyan legal system integrates the English Property law (private land), African customary law (community land), and feudal socialist sense of land as a property of the State, (public land). This has been the traditional practice in balancing rights in land law which has never gone without serious constitutional challenges of the recent years thereof.

While the economic environment keeps on changing, land ownership and its subsequent use, stand at the centre of several conflicting interests. For instance, Kenya needs land for its economic growth in terms of agricultural activities and food produce, both to feed her citizens, and also to export, for foreign exchange. At the same time, Kenya embraces capitalist conception of land as a real estate for commercial benefits, making it a core element of business and accruing of interest rates to favour her economic growth. Both needs are also pegged on the questions of other rights such as land protection, soil conservation under environmental law and policies. All this comes with conflict of various interests that have not been easy to balance and harmonise into a corpus juris such as Land Act.

\section{c) The Report of the Kenya Land Commission of 1933}

The report of the Kenya Land Commission of September 1933 was to recommend measures for righting wrongs if any, done by earlier disposition of land, whether by omission or commission, "to communities, bodies, individual natives, tribal or detribalized". ${ }^{25}$ Thus they had to discuss native requirements, and native rights.

The Commission recommended that the native occupation should be classified under 4 heads: Class A - Native lands, comprising existing reserves, and some additions to be made on grounds of historical right or continuous use; Class B Native reserves ${ }^{26}$ This may be confusing and should be carefully differentiated at the outset. They all come under class A. Native lands in future are to mean lands given by the Government out of Crown lands. ${ }^{27}$

The Commission already spells out the distinction between the Native Lands, Native Reserves and the Crown Land (Crown Lands Ordinance of 1915). Public land was the Land considered as the Crown Land (Crown Lands Ordinance of 1915) which was under the Government of the

25 'CAB/24/248 The Kenya Land Commission Report (1934)' (Scribd) $<$ http://www.scribd.com/doc/74835533/CAB-24-248-The-Kenya-Land-Co mmission-Report-1934> accessed 17 August 2014

26 Ibid.

27

http://www.jstor.org/discover/10.2307/716465?uid=3738640\&uid=2129\&u $\mathrm{id}=2 \&$ uid $=70 \&$ uid $=4 \& \mathrm{sid}=21104597622493$ See Journal of the African Royal Society, 1901-1944, Oxford University Press, Vol. XXXIII, 1934 (Vol. 1-43); See also African Affairs, Oxford University Press, 1944-2006, (Vol. 406, No. 422, Vol. 112, No. 446). 
Great Britain. The "White Settlers" were apportioned most of the fertile lands meant for farming and resettlement of the white farmers mostly from South Africa and England. ${ }^{28}$

It is also clear to the knowledge of the public that the reports from the Kenya Land Commission 1933 is full of unresolved demands including inter alia ethnic minorities namely the Ogiek community whose rights in land law is nothing closer to lasting and definite solution. A question attracting the attention of human rights lawyers as well as social justice lawyers in Kenya and beyond. For indigenous minority communities, such as the Ogiek the relationship with land is not merely a question of possession and production but a material and spiritual element, which they should fully enjoy as well as means to preserve their cultural heritage and pass it on to the future generations. ${ }^{29}$

Kenya Land Commission Report was based on the British colonial perception that African farmers did not require title to land. A system of registration of titles based on English law model was introduced within the colony after the recommendations of the East African Royal Commission which advocated for adjudication and registration of individual titles. 30

\section{Land Tenure and Agrarian Reform in Kenya}

Simon Coldham puts it nicely that most Kenyan Africans have always lived and worked on land. ${ }^{31}$ The hard nut to crack in the Kenyan land law is how to break up with the colonial brainwashing and enact laws that would recognise customary land tenure or do away with it. It is also correct to believe that dally dallying with historical corruption and impunity as means of retaining power is not good for the balancing of rights mechanism.

It is wrong to say that there are institutions and proper laws in place if the system cannot address serious elements of misrule and enforce the rule of law. If policies and laws cannot address various interests and converge with some pragmatic means, then politics shall always grab the occasion and make land reform process practically untenable. Politicians have no sense of public rights while most of them pursue personal gains. The sense of public good in Kenya is very weak and needs correction. ${ }^{32}$ It is not easy to think of agrarian reform with no sense to public common good in a democracy such as Kenya.

\section{Balancing Rights in Land Law}

The constitutional rights, customary rights, and legislative

28 Southall (n 3).

$29 \mathrm{http}: / /$ freeafrica.tripod.com/ogiekland/book/Chapter05.htm

30 Simon FR Coldham, 'Land-Tenure Reform in Kenya: The Limits of Law' (1979) 17 The Journal of Modern African Studies 615.

31 Angelique Haugerud, 'Land Tenure and Agrarian Change in Kenya' (1989) 59 Africa: Journal of the International African Institute 61.

32 Matthews and Coogan, 'Kenya and the Rule of Law' (n 2). rights are all contained in one corpus juris, the land law. The same land law comprises of the constitution, land Act, Registered Land Act, Land Acquisition Act, Public Land Act, National Reserves Act, Community Land Act, Forests Act, Land and Environmental Court Act, and African Customary Land Tenure. Such laws are designed to deal with boundary disputes, to make titles secure, to render conveyancing process simple, safe and cheap. ${ }^{33}$ However, land law in Kenya does not go without technical challenges. Kenya has land control Board under the Ministry of lands whose main mandate includes inter alia balancing of rights in land law.

Before a registered proprietor disposes of land, he must appear before the Board together with the new acquiring party. The Board establishes that the proprietor expresses his or her intent to sell the property and the party acquiring must also express the intent to acquire the title.

Another new regime entrenched in the new constitution is the National Land Commission (section 67 of the constitution of 2010) whose mandate includes inter alia to (a) manage public land on behalf of the national and county governments; (b) to recommend a national land policy to the national government; (c) to advise the national government on a comprehensive programme for the registration of title in land throughout Kenya; (d)to conduct research related to land and the use of national resources, and make recommendation to appropriate authorities; (e) to initiate investigations, on its own initiative or on a complaint, into present or historical land injustices, and recommend appropriate redress.

The Kenya National Commission has to generate mechanisms that would resolve problems related to land grabbing, land distribution, conveyancing and make recommendations to the national government. However, despite the above constitutional mandate the KNLC has been in litigation with the Cabinet Secretary of the Ministry of Lands. The controversy among the constitutional institutions is also caused by who has the rights to manage the public lands. It is power struggle that still creates more confusion in the management of public lands.

Any balancing of rights on land law must take into account several interest groups or stakeholders. Ethnic communities, their lifestyle and means of livelihood, development objectives of the State, communities and individuals, environmental interests, political economy, cultural interests of every social group, and economic vigour represented by the business community. Any policy and law on land must consider a range of rights that may clash.

The given historical injustices on land tenure and distribution have impact on the balancing of rights in land in the modern Kenya. Colonial legacy, domination of political elite, the community of African bourgeoisie, the urbanization, need for development and new constitutional administrative system in 47 counties are all areas that require serious academic debate when it comes to rights in land law.

Kenya is one of the most rapidly expanding economies in

33 Coldham, 'Land-Tenure Reform in Kenya' (n 30). 
the recent years. The urban population growth is also steadily growing with many jobless youth. This reality makes rights in land tenure especially in the urban sectors very competitive and crucial. Individuals who cannot own land in the urban area or rent a dignified habitation usually find themselves in informal urban settlements. Such settlements known as slums do not meet the requirements of international human rights despite the constitutional requirements under the Bill of Rights.

As the population growth of Kenya is steadily expanding need for more space of land is also relatively increasing. For instance, in Nairobi several persons purchase lands among the Masai land owners. The investors turn such lands into commercial use and put up buildings for sale. The trend is threatening the rights of the Masai who require graze lands for their livelihood and economy.

Land-grabbing in Kenya has been at the centre of national debates. ${ }^{34}$ Individuals with money hunt for any space of land including designated community lands and public lands. Land-grabbing in Kenya is alleged as one of the most frequent crimes in the land law. Such rampant land grabbing lead to violence, conflicts and disputes. Some cases of killings due to land-grabbing and lack of proper regulations in balancing rights in land law have been reported in the case law in Kenya.

It is noted that politicians have used land rights as means for their campaign trails and to get loyal votes from the citizens and retain power. ${ }^{35}$ However, most of them have no clear idea of how to summarily deal with the balancing of rights in land law and to come up with lasting solutions to the vice.

Land grabbing has been linked to poverty and failure to access justice by the low income individuals. ${ }^{36}$ In some remote rural sectors some individuals have unjustly lost their lands to powerful grabbers. Farmers with no proper income usually end up losing their lands or selling them cheaply to individuals with money. Such buyers usually use land as commercial property rendering villagers with little income paupers and landless. The best example is the eventful conflict known in Kenya as the Sabaot Land Defense Force $(\mathrm{SLDF})^{37}$ around Mount Elgon in 2005. ${ }^{38}$ Parents of Sabaot sub-tribe sold their proprietorship of lands to rich buyers from outside the area, who later turned them into commercial and residential use. The siblings of the vendors later became squatters. A situation which forced them to re-organize themselves, and engage in violent criminal acts against the perceived new land owners in the region. The Government used inherited colonial military intervention ${ }^{39}$ to quell the disputes but there is no mention of the due process of law for the complainants. ${ }^{40}$

MRC (Mombasa Republican Council) ${ }^{41}$ was formed in the Coastal region to combat against landlords and reclaim lands that had been acquired by individuals, families and groups from outside the region. The Government quashed the militant group yet the question of land tenure in the Coastal region persist. The recent Mpeketoni conflict around Lamu town in Kenya had links with historical injustices on land. Squatters or the landless usually turn hostile against landlords committing crimes to civilians. ${ }^{42}$

The affected individuals are persons living under poverty level. They find themselves and their families living in poverty. The Government has never managed to come up with policies and laws effective enough to ensure that rights in land law address the needs of the citizens in an equitable and acceptable manner.

Minority ethnic communities in Kenya have raised their concern on the distribution of lands in a manner that contemplate socio-economic and cultural status of such groups. An example is the Ogieki and Endroi communities and many others whose interests have not been properly addressed by policies and laws of Kenya.

Balancing of rights in land law has become controversial in the recent years. Policy and law makers grapple with population growth, poverty level, interests in land, economic, social and political domination of fertile lands by bourgeoisie class. The system favours the wealthy individuals in the market theory trend versus the poor whose interests are not addressed by the Government. This leads to alienation of rights on the titles to land based on economic capacity of individuals to appropriation of land titles.

Kenya is a capitalist State. Her ideology has embraced rightist politics in which the regime does not emphasize on the social needs of individuals who are not able to compete and defend their rights to land. Such is one of the difference between the socialist system in Tanzania where the Ujamaa ideology ${ }^{43}$ did not endorse English perception of land as a commercial property. Land tenure and policy in the Ujamaa system contemplates communal ownership other than private ownership. ${ }^{44}$ Kenya embraced the English Property Law that considers land as real estate that one can acquire and dispose of.

Since the independence in 1963 the Kenyan Governments have put in place Land Commissions, Land Reform Commissions, Law and other institutions including the Ministry of Land. The Constitution of 2010 has a provision of Land and Environmental Court, a judicial approach to deal with disputes over land.

40 'Sabaot Land Defence Force' (n 38).

41 'Mombasa Republican Council', , Wikipedia, the free encyclopedia (2014)

$<$ http://en.wikipedia.org/w/index.php?title=Mombasa_Republican_Council \&oldid=619203971 $>$ accessed 18 August 2014 .

42 Ibid.

43 Harrison C Dunning, 'Review' (1973) 21 The American Journal of Comparative Law 796.

44 Ibid. 


\section{Land Law In Kenya}

Section 61 of the Constitution of Kenya holds that All lands in Kenya belongs to the people of Kenya collectively as a nation, as communities and as individuals. ${ }^{45}$ Lands in Kenya are classified either as public, community or private. Public land (Sec. 62); Community land (Sec. 63); and Private land (Sec. 63) are entrenched in the Constitution of 2010. Public land is defined by the constitution as land which at the effective date was an unalienated government land as defined by an Act of Parliament in force; Community land is defined as land lawfully registered in the name of group representatives under the provision of any law; Private land is defined as registered land held by any person under any freehold tenure, land held by any person under leasehold tenure, and any other land declared private land under an Act of Parliament.

Despite the constitutional interpretation of "land" still legal technicality in land law - how to deal with the past, present and future (environmental law); political economy and land use; privatization of land and Land holding are all problematic in the Kenyan legal system and jurisprudence in Land are one of the areas to be developed by the Kenya National Land Commission under section 67 of the Constitution of 2010.

Private acquisition of land with titles under freehold tenure or leasehold tenure, confers rights to individuals or legal personalities that can make use of them or dispose them according to the law in force. Private landlords can make any commercial use of the land provided that it is within the law enabling them to exercise rights of property and possession over the land. The same provision allows one to transfer such rights through succession or through sale of goods agreements.

Community land acquisition refers to chunks of lands that still maintain the traditional land ownership (customary land tenure) and trustee (Section 63(3) of the Constitution holds that any unregistered community land shall be held in trust by county governments on behalf of the communities for which it is held. Which are the communities for which such land is held as trust?

The use of ethnic groups to refer to a region such as Masai province, Nandi province, Kikuyu province, Kamba province had been known since the colonial time; however, the constitution of Kenya has not overruled the use of the title community land to refer to a terrestrial space allocated for common usage for pastoralist communities- the basic idea is to enable pastoralist to exercise their need for free grazing and respect the economic needs for such traditional communities. ${ }^{46}$ It is also anchored on the communities in so far as they are divided along ethnic line, clans and conglomeration of families that live in a cluster in given specific location and exercise more or less similar economic

45 John W Harbeson, 'Land and the Quest for a Democratic State in Kenya: Bringing Citizens Back In' (2012) 55 African Studies Review 15.

46 'Acquisition and Use of State Lands in Africa: A Bibliography' (1970) 3 African Law Studies 23. activity of which land issue is indispensable.

Kenya is particularly unique as ethnic groups are still perpetuating traditional "tribal lands" which are not constitutional but existing in practice under the guise of traditional societies in rural sectors of favour of tribal politics. Such tribal lands are inherited from the perception of the British colonial term of "native lands" similar to former "bantustans in South Africa during apartheid regime" such as Kuria, Gusii, Kikuyu, Luo, Kipsigis, Kamba, Meru, Embu, Samburu, Masai, Taita, Digo, Luhya, Giriama, Nandi and so on. Such perceptions and undertones still persist under customary land tenure but lack proper recognition of the State law. Such traditional perception and politics over customary land tenure determines how the government decides on its policies on land.

In Kenya, customary land tenure and traditional ethnic perceptions on right in land have been the basis of gruelling conflicts. In 1992 and $2002,{ }^{47}$ tribal rivalry ${ }^{48}$ has been politicised to an extent that caused ethnic conflicts and land clashes as has been comprehensively revealed in the Kroll Report of $1992 .{ }^{49}$

Despite the entrenchment of land law in the constitution 2010 there are enough grounds to believe that the conflicts ${ }^{50}$ over land issues in Kenya shall continue for more time unless historical injustices are seriously addressed. ${ }^{51}$ The reason is that most of the trouble facing balancing of rights in land law issues is linked to ethnic politics and historical biasness in the system. ${ }^{52}$ Land politics in Kenya is a redistributive game that creates winners and losers. ${ }^{53}$ There is no guarantee that the legislators and the citizens shall agree on common mechanism to adopt and deliver services to the people especially concerning balancing rights in land.

In practice customary law and politics keep on determining the distribution of land among several communities in Kenya. ${ }^{54}$ Succession Act in Kenya includes customary transfer of land from father to children according to the customary law of the concerned persons. Attempts to suppress customary civil law concerning land acquisition have not yielded any fruit. A father would pass his land to the next of kin pursuant to the Succession Act and in case of lacunae the law courts usually refer such disputes to the council of elders for alternative dispute resolution mechanism.

\section{Comparing Notes with Tanzania}

47 Matthews and Coogan, 'Kenya and the Rule of Law' (n 2).

48 Robert M Press, 'Tribal Clashes Disrupt Kenya' [1992] Christian Science Monitor <http://www.csmonitor.com/1992/0629/29141.html> accessed 18 August 2014.

49 '1992 Tribal Clashes "Were Instigated by Biwott "Business Associate' $<$ http://kenvironews.wordpress.com/2007/09/04/1992-tribal-clashes-were-i nstigated-by-biwott-\%e2\%80\%98business-associate $\%$ e $2 \% 80 \% 99 />$ accessed 18 August 2014

50 Press (n 48).

51 Boone (n 11).

52 Matthews and Coogan, 'Kenya and the Rule of Law' (n 2).

53 Jenny (n 1).

54 Coldham, 'Land-Tenure Reform in Kenya' (n 30). 
The question of land titles to privates in Socialist Republic of Tanzania was adapted in line with Mr. Julius Nyerere's Ujamaa system passed at Arusha Declaration of $1967 .{ }^{55}$ The Declaration defines socialism to include, absence of exploitation, public control of the major means of production, democracy, and a major personal socialist life for the nation's leaders. ${ }^{56}$ Ujamaa is a socialist system that regards land ownership as the prerogative of the public interest (ujamaa) as so long as such communities use the land for productivity. The land title is held by the State as opposed to "private land" tenure in Kenya. Such theory of Nyerere reduced conflicts and disputes based on land tenure in Tanzania but did not influence the neighbouring Kenya which was under the influence of Euro-American capitalist ideology. Tanzania adopted Socialist system ${ }^{57}$ which advocated the communal land ownership even though Nyerere adjusted the socialist ideas to adapt African system of thought. Hard work was promoted rather than money and agriculture rather than industry. 58 An approach that made land issue in the future Tanzania a question of prioritizing on community values based on African socialism. ${ }^{59}$

The balancing of rights in land law in Tanzania was designed in line with African customary law and in the interest of the 120 tribes of Tanzania as opposed to English Common law. The conception of interests in land, were in accordance with African practice and such approach saved Tanzania from many land crimes as opposed to her counterpart Kenya. However, even the Ujamaa system had its undesirable consequences including exploitation of women and increased poverty.

\section{The Botched Ndung'u Commission Land Report}

In what could be termed as a waste of tax payers' money, the Government established Land Commission known as Ndung'u report ${ }^{60}$ (2003) that had never been brought to the consideration by law and policy makers prior to the ratification of the constitution in $2010 .^{61}$

Such failure based on political will has contributed to the flop of justice in land. The report revealed adverse corruption, subservience to the executive ${ }^{62}$ and cartels in land deal involving very powerful individuals. Political influence in rights in land law has also been revealed in the TJRC report of 2013 in which the Commissioners made various observations and made recommendations which later on were alleged as doctored. The report emphasized on illegal and irregular allocation of public land. It majored on graft

55 Dunning, 'Review' (n 43).

56 Harrison C Dunning, 'Review' (1973) 21 The American Journal of Comparative Law 796.

57 Ibid.

58 Ibid.

59 Dunning, 'Review' (n 43)

60 Southall (n 3$)$

61 Harbeson (n 45)

62 Matthews and Coogan, 'Kenya and the Rule of Law' (n 2). over land in Kenya. ${ }^{63}$

One success in this report is that its exposure compelled some lands to be returned to the Government by politicians. ${ }^{64}$ Land underlies Kenyan giant political economy and the study has revealed this.

There was systematic way in which procedures designed to protect public land rights were public land rights into private ownership rights. The beneficiaries are politically connected individuals with power and money. ${ }^{65}$

Economically Kenya performed better than Socialist Ujamaa in Tanzania. Capitalism created more impetus for competitiveness and rapid economic growth. However, such market based theory from the Euro-American capitalist system did not go without serious legal implications when it comes to equitable access to land (under section 60(1)(a) of the Constitution 2010).

\section{Some Land Law Cases}

Failure to deal with balancing of rights in land law in an effective manner has been the basis for several court disputes over land law cases in Kenya. Over-reliance on foreign case law and failure to develop pragmatic jurisprudence on land are also contributors to more problems in the Kenyan judicial system.

Best v Chief Lands Registrar (2014) EWHC 1370 (Admin), The court considered the effect of $s .144$ Legal Aid, Sentencing and Punishment of Offenders Act 2012 on adverse possession claims. S.144 LASPOA creates a criminal offence of trespass and the Chief Land Registrar had held that a person could not rely on his own criminal act in seeking to make out an adverse possession claim. The court disagreed with the Registrar, extensively reviewing the case law and statutory history and concluding that there was no Parliamentary intention ... http://www.casecheck.co.uk/ CaseLaw.aspx? EntryID $=20471 \&$ CaseType $=$ Property \&Case Title $=$ Best $+\mathrm{v}+$ The + Chief + Land\#sthash.PYcXB4wk.dpuf

The above case proves that adverse possession right over land has been challenged when the court was not persuaded otherwise. Under the environment and land cases, the High Court and Court of Appeal receive several complaints relevant to the conflict of interests in land. Most of such cases involve the question of balancing of rights in land when it comes to individual ownership. A number of land law cases involve grafts and cartels in land. The High Court deals with such cases in separation but maintain procedural civil law and criminal law principles derived mostly from the borrowed English Common Law.

Most of the judgments draw close attention to the case law which relies on past rulings made by other courts on similar cases even outside the Kenyan jurisdiction. An example is the case of Simon Njii Mwangi v Andrew Sammy Musyoki [2014] eKLR, The conditions for the grant of an interlocutory injunction are now, I think, well settled in East

63 Southall (n 3).

64 Ibid.

65 Ibid. 
Africa. First, an applicant must show a prima facie case with a probability of success. Secondly, an interlocutory injunction will not be normally granted unless the applicant might otherwise suffer irreparable injury which would not adequately be compensated by an award of damages. Thirdly, if the court is in doubt, it will decide an application on the balance of convenience.

\section{Conclusive Remarks}

Debates on land law are varied however the interest of this research is limited to analysing criteria adopted by the Kenyan Government to balance rights in land law. It is concerned with studying whether such adopted mechanisms have been effective or not and why?

Land law has been very contentious in Kenya. Proper balancing mechanism has not been developed. Reasons pegged to this failure in the system are anchored on several factors that we have discussed in this paper.

Acknowledging that every socio-economic context and every State has its own approach in dealing with land, it is correct to admit that whatever mechanism Kenya has adopted worth academic consideration without prejudice. The Republic of Kenya is known for its capitalist system and its faithfulness to English Common Law and such choice should not be judged as bad. What is important is to develop flexibility in the research system and to encourage more debates, open forums, national dialogue, and reforms. For instance, constitutional change in itself is not bad. It can be done frequently as so long as the State manages to come up with a mechanism that would enable balancing of rights and avoid conflicts.

The research finally reveals that Kenyan system falls short of the required international minimum standards of human rights concerning acquisition and distribution of land. However, we are also cognizance of new developments especially the new constitution, Environment and Land court and new effort made by policy makers in both levels of Government. After years of struggle to get lasting solution to conflicts and violence related to historical injustices over land in Kenya, the nation shall conclusively seal its long debate about justice on land. But before all this is said and done there must be transparency, equity, and inclusiveness in the matters of public concern. Constitutionalism and the rule of law must be taken seriously and decisively.

\section{REFERENCES}

[1] '1992 Tribal Clashes "Were Instigated by Biwott ”Business Associate'

$<$ http://kenvironews.wordpress.com/2007/09/04/1992-tribalclashes-were-instigated-by-biwott- $\% \mathrm{e} 2 \% 80 \% 98$ business-ass ociate $\%$ e2\%80\%99/> accessed 18 August 2014

[2] 'Acquisition and Use of State Lands in Africa: A Bibliography' (1970) 3 African Law Studies 23
[3] Boone C, 'Land Conflict and Distributive Politics in Kenya' (2012) 55 African Studies Review 75

[4] 'CAB/24/248 The Kenya Land Commission Report (1934)' (Scribd)

$<$ http://www.scribd.com/doc/74835533/CAB-24-248-The-K enya-Land-Commission-Report-1934> accessed 17 August 2014

[5] Coldham SFR, 'Land-Tenure Reform in Kenya: The Limits of Law' (1979) 17 The Journal of Modern African Studies 615

[6] 'Land-Tenure Reform in Kenya: The Limits of Law' (1979) 17 The Journal of Modern African Studies 615

[7] Dunning HC, 'Review' (1973) 21 The American Journal of Comparative Law 796

[8] 'Review' (1973) 21 The American Journal of Comparative Law 796

[9] Harbeson JW, 'Land and the Quest for a Democratic State in Kenya: Bringing Citizens Back In’ (2012) 55 African Studies Review 15

[10] Haugerud A, 'Land Tenure and Agrarian Change in Kenya' (1989) 59 Africa: Journal of the International African Institute 61

[11] Jenny F, 'Cartels and Collusion in Developing Countries: Lessons from Empirical Evidence' (2006) 29 World Competition 109

[12] Matthews K and Coogan WH, 'Kenya and the Rule of Law: The Perspective of Two Volunteers' (2008) 60 Maine Law Review 561

[13] 'Kenya and the Rule of Law: The Perspective of Two Volunteers' (2008) 60 Maine Law Review 561

[14] 'Mombasa Republican Council', , Wikipedia, the free encyclopedia (2014) <http://en.wikipedia.org/w/index.php?ti tle $=$ Mombasa_Republican_Council\&oldid $=619203971>$ accessed 18 August 2014

[15] Newsinger J, 'Revolt and Repression in Kenya: The "Mau Mau” Rebellion, 1952-1960' (1981) 45 Science \& Society 159

[16] 'Ogiek Land Cases and Historical Injustices by Towett J. Kimaiyo'

$<$ http://freeafrica.tripod.com/ogiekland/book/Chapter05.htm> accessed 17 August 2014

[17] Press RM, 'Tribal Clashes Disrupt Kenya' [1992] Christian Science Monitor <http://www.csmonitor.com/1992/0629/29 141.html $>$ accessed 18 August 2014

[18] 'Sabaot Land Defence Force', Wikipedia, the free encyclopedia (2014)

$<\mathrm{http} / / /$ en.wikipedia.org/w/index.php?title=Sabaot Land De fence_Force\&oldid $=608106094>$ accessed 18 August 2014

[19] Southall R, 'The Ndungu Report: Land \& Graft in Kenya' (2005) 32 Review of African Political Economy 142

[20] Wilkinson HW, 'Law Commission: Transfer of Land. Report on Restrictive Covenants' (1967) 30 The Modern Law Review 681 